\title{
Irfani
}

ISSN 1907-0969 E ISSN 2442-8272

Volume 14 Nomor 1 Juni 2019

Halaman 93-97

http://journal.iaingorontalo.ac.id/index.php/ir

\section{EVALUASI PROGRAM PEMBINAAN KARAKTER BERBASIS AGAMA DI MADRASAH IBTIDAIYAH MUHAMMADIYAH GORONTALO}

\author{
Muhammad Mursyid \\ (Universitas Muhammadiyah Yogyakarta) \\ Email: mursyid13@gmail.com
}

\begin{abstract}
ABSTRAK
Penelitian ini bertujuan untuk mengetahui perencanaan program pembinaan karakter siswa berbasis agama di madrasah ibtidaiyah Muhammadiyah Gorontalo, mengetahui pelaksanaan program pembinaan karakter siswa berbasis agama di madrasah ibtidaiyah Muhammadiyah Gorontalo, dan mengetahui kendala dari pelaksanaan program pembinaan karakter siswa berbasis agama di madrasah ibtidaiyah Muhammadiyah Gorontalo. Penelitian ini merupakan penelitian kualitatif dengan mengambil latar Madrasah Ibtidaiyah Muhammadiyah Gorontalo. Pengumpulan data dilakukan dengan menggunakan metode observasi, wawancara mendalam dan dokumentasi. Analisa data dilakukan dengan analisis kualitatif. Pemeriksaan keabsahan data dilakukan dengan metode triangulasi dengan membandingkan data hasil pengamatan dengan data hasil wawancara, dan membandingkan hasil wawancara dengan isi suatu dokumentasi yang berkaitan dengan penelitian.Hasil penelitian ini menunjukkan 1) Perencanaan program pembinaan karakter berbasis agama di Madrasah Ibtidaiyah Gorontalo telah direncanakan dan dirancang dengan menanamkan nilai - nilai karakter, seperti (a) kejujuran (b) kedisiplinan (c) religious (d) kerjasama (e) tanggung jawab (f) dan percaya diri. 2) pelaksanaan program program pembinaan karakter berbasis agama di Madrasah Ibtidaiyah Gorontalo dilakukan dengan cara (a) cerita tentang keteladanan di kelas (b) kerja kelompok di kelas (c) bakti sosial (d) kunjungan ke panti asuhan (e) infak setiap hari jumat (f) kantin kejujuran (g) lomba - lomba atau kompetisi yang dilakukan di setiap tahunnya, seperti lomba bercerita, membaca puisi dan ESQ untuk siswa akhir. 3) kendala pelaksanaan program pembinaan karakter berbasis agama di Madrasah Ibtidaiyah Gorontalo adalah (a) factor kendaraan (b) kondisi siswa yang baru mengenal pengetahuan tentang agama (c) beberapa orang tua peserta didik yang kurang akan pengetahuan agama (d) lingkungan tempat tinggal sebagian peserta didik kurang mendukung.
\end{abstract}

Kata Kunci : Evaluasi, Program Pembinaan, Karakter 


\section{A. Pendahuluan}

The founding father menyatakan bahwa terdapattiga tantangan besar yang harus dihadapi oleh bangsa Indonesia untuk menjadi bangsa yang besar yaitu negara yang bersatu dan berdaulat, membangun bangsa dan membangun karakter dimana ketiga tantangan tersebut secara jelas tampak dalam konsep negara bangsa (nationstate) dan pembangunan karakter bangsa (nation and character building). Bung Karno, Presiden pertama Republik Indodesia menegaskan bahwa bangsa ini harus dibangun dengan mendahulukan pembangunan karakter (character building), karena character building inilah yang akan membuat Indonesia menjadi bangsa yang besar, maju dan jaya, serta bermartabat. Apabila upaya tersebut tidak dilakukan dengan baik, maka bangsa Indonesia akan menjadi bangsa kuli (Samani \& Hariyanto, 2013).

Mengingat begitu pentingnya pembangunan karakter bagi kemajuan bangsa Indonesia, maka terhitung sejak tahun 2010 pemerintah Indonesia mencanangkan pembangunan budaya dan karakter bangsa yang diawali dengan dideklarasikannya pendidikan budaya dan karakter bangsa sebagai gerakan nasional. Hal tersebut dilakukan mengingat semakin merosotnya nilai karakter dan norma dalam berbangsa dan beragama. Pendidikan dianggap sebagai alternatif yang bersifat preventif dengan tujuan untuk membangun generasi penerus bangsa yang lebih baik (Kemdiknas, 2010).

Meninjau dari uraian diatas dibentuklah Undang-Undang mengenai Sistem Pendidikan Nasional pasal 1 ayat 5 dinyatakan bahwa "Pendidikan nasional adalah pendidikan yang berdasarkan Pancasila dan UUD 1945 dan perubahannya yang bersumber pada ajaran agama, keanekaragaman budaya Indonesia serta tanggap terhadap perubahan zaman”. Disinilah pentingnya pendidikan khususnya pendidikan karakter yang berbasis pada nilai-nilai agama, disamping nilai-nilai yang tumbuh dalam kebudayaan Indonesia. Khusus pendidikan karakter yang berbasis pada agama memiliki dasar-dasar nilai fundamental dan universal tetang kehidupan, termasuk kehidupan di bidang moral atau akhlak untuk menjadikan manusia berada dalam fitrahnya selaku makhluk Tuhan yang beradab (Nashir, 2013).

Untuk dapat mewujudkan isi dari undang-undang tersebut, upaya yang dapat dilakukan adalah dengan memaksimalkan fungsi mata pelajaran agama di sekolah atau madrasah. Guru pendidikan agama islam bersama dengan guru yang lain dapat merancang berbagai aktivitas sehari - hari bagi siswa di sekolah yang diwarnai dengan nilai agama. Dengan cara demikian, siswa Madrasah Ibtidaiyah muhammadiyah Gorontalo diharapkan dapat terbiasa untuk melakukan aktivitas aktivitas keagamaan yang pada akhirnya dapat membentuk karakter dengan baik. 


\section{B. Metode Penelitian}

Penelitian ini difokuskan pada evaluasi program pembinaan karakter pada Madrasah Ibtidaiyah kota Gorontalo. Agar hal yang di teliti dapat terungkap dengan baik dan memberikan gambaran yang sebenarnya diperlukan pengamatan yang mendalam guna memperoleh data yang lebih lengkap dan rinci. Oleh karena itu, penelitian ini menggunakan pendekatan kualitatif dengan rancangan studi kasus.

Penelitian kualitatif adalah suatu proses penelitian yang dilakukan secara wajar dan natural sesuai dengan kondisi objektif di lapangan, serta jenis data yang dikumpulkan terutama adalah data kualitatif. Penelitian yang dimaksud adalah dengan melakukan pengamatan terhadap objek penelitian dalam melakukan kegiatan sehari - hari, berinteraksi dengan objek penelitian dan berupaya memahami bahasa dan tafsiran mereka tentang dunia sekitarnya. Pada penelitian kualiotatif, peneliti harus terjeun ke lapangan guna mendapatkan data yang valid. Teknik pengumpulan data dilakukan secara triangulasi yang sekaligus digunakan sebagai teknik dalam uji keabsahan data yaitu dengan cara observasi berperan serta, wawancara mendalam dan studi dokumentasi. Sedangkan teknik analisa data pana penelitian ini adalah menggunakan tiga tahapan yaitu mereduksi datam display data dan penarikan kesimpulan

\section{Hasil dan Pembahasan}

Perencanaan program pembinaan karakter yang dikembangkan oleh Madrasah Ibtidaiyah Muhammadiyah Gorontalo berangkat dari visi dan misi serta tujuan yang hendak dicapai oleh Madrasah dengan secara langsung mengimplementasikan penanaman nilai karakter. Setelah disusunnya visi, misi dan tujuan madrasah selanjutnya dijabarkan ke dalam berbagai program kegiatan dengan terlebih dahulu melakukan perancangan program dan dan kegiatan penanaman karakter oleh madrasah diantaranya adalah sikap religius, jujur, toleransi, disiplin, kerja keras, kreatif, mandiri, demokratis, rasa ingin tahu, semangat kebangsaan, cinta tanah air, cinta damai, peduli lingkungan, peduli social, dan adanya rasa tanggung jawab.

Beberapa nilai karakter yang diusung oleh madrasah Ibtidaiyah Muhammadiyah Gorontalo yang tertuang dalam visi, misi dan tujuan tersebut tidak akan dapat terwujud apabila penanaman yang dilakukan tidak secara terus - menerus. Diperlukan adanya kerjasama antar lintas sector di dalam lingkungan sekolah maupun diluar lingkungan sekolah seperti pengawasan dari orang tua. Sehingga, dengan adanya upaya tersebut, penanaman nilai karakter akan berubah menjadi kebiasaan siswa dalam mengimplementasikan nilai karakter dalam kehidupan sehari hari. keberhasilan tersebut yang akan menjadi bagian penting dalam mewujudkan masyarakat global yang berkeadaban secara bertahap (Sahlan dan Prastyo, 2012 : 3940).

Berdasarkan hasil wawancara dengan salah seorang guru agama menunjukkan bahwa nilai karakter yang ditanamkan di Madrasah Ibtidaiyah Muhammadiyah Gorontalo sudah berjalan namun belum menjadi prioritas utama dalam setiap kegiatan belajar mengajar. Hal tersebut terlihat dari tercantumnya tujuan penanaman nilai karakter pada setiap visi dan misi serta tujuan dari lembaga sekolah. Menurut Elkind 
dan Sweet (2004) dalam (Samani dan Hariyanto, 2013:139) menyatakan bahwa praktik persekolahan di Amerika Serikat terkait dengan pembinaan karakter dilaksanakan dengan pendekatan holistik. Artinya seluruh warga madrash harus terlibat dan bertanggung jawab terhadap pelaksanaan pembinaan karakter, sehingga program tersebut tidak hanya tercantum dalam visi, misi dan tujuan namun dapat terlaksana dengan baik di setiap kegiatan sekolah.

Dilihat dari realita lapangan yang diamati oleh peneliti, didapatkan bahwa penanaman karakter yang dilakukan oleh pihak madrasah sudah terintegrasi dalam setiap kegiatan belajar mengajar dan dilakukan oleh setiap lini di madrasah tersebut. Selanjutnya, program - program pembinaan karakter dari visi dan misi dikembangkan lebih luas menjadi aturan dan tata tertib madrasah sebagai salah satu bentuk controlling dari penanaman sikap yang baik. Selain dicantumkan dalam bentuk tata tertib, penanaman nilai karakter juga dapat dilakukan melalui kegiatan intrakulikuler dan ekstrakulikuler. untuk Kegiatan yang dilakukan melalui intrakulikuler dapat dilakukan melalui metode ceramah, bercerita tentang keteladanan dan kerja kelompok. Sedangkan pembentukan karakter melalui kegiatan ekstrakulikuler dapat dilakukan dengan kegiatan bakti social, pengumpulan infak untuk disalurkan ke panti asuhan, wisata dakwah, dan kegiatan ESQ untuk kelas akhir menjelang ujian nasional.

Dalam pelaksanaannya, kendala yang sering diahadapi oleh pihak madrasah adalah hal - hal baru yang ditemukan di dunia luar, kurangnya controlling orang tua dalam hal sholat dan kegiatan agama lainnya, pengaruh negative televisi, pergaulan bebas, dampak buruk dari internet, dan dampak burut arus urbanisasi.

\section{Kesimpulan}

Dari hasil penelitian yang telah dilakukan, dapat ditarik kesimpulan bahwa : perencanaan program pembinaan karakter berbasis agama di Madrasah Ibtidaiyah Muhammadiyah Gorontalo telah direncanakan dan dirancang dengan menanamkan nilai karakter berupa kejujuran, kedisiplinan, religus, kerjasama, tanggung jawab dan percaya diri. Pelaksanaan program pembinaan karakter berbasis agama di Madrasah Ibtidaiyah Muhammadiyah Gorontalo dilakukan dengan cara pemaparan tentang keteladanan, kerja kelompok, bakti social, kunjungan ke panti asuhan, infak setiap jumat, lomba dan kompetisi. Kendala pelaksanaan program pembinaan karakter berbasis agama di Madrasah Ibtidaiyah Gorontalo adalah factor kendaraan, kondisi siswa yang baru mengenal tentang pengetahuan agama, bebrapa orang tua peserta didik yang kurang akan pengetahuan agama dan tidak peduli serta lingkungan tempat tinggal sebagian peserta didik kurang mendukung.

\section{E. Daftar Pustaka}

Arikunto, S. 1990. Manajemen Pendidikan. Yogyakarta: Aditya Media bekerja sama dengan FIP Universitas Negeri Yogyakarta,

Bafadal, I. 1995. Proses Perubahan di Sekolah (Studi Multisitus Pada Tiga Sekolah Dasar Yang Baik). Disertasi tidak diterbitkan. Malang: PPs Univessitas Negeri Malang. 
Borba, M. 2008. Membangun Kecerdasan Moral: Tujuh Kebajikan Utama Agar Anak Bermoral Tinggi. Terj. oleh Lina Jusuf. Jakarta: PT. Gramedia Pustaka Utama.

Faisal, S. 1990. Penelitian Kualitatif. Dasar-dasar dan Aplikasi. Malang: Yayasan Asah Asih Asuh

Depdiknas RI. 2004. Pengembangan karakter Sekolah. Jakarta: Depdiknas RI.

Samani, M \& Harianto, M.S. 2013. Konsep dan Model Pendidikan Karakter. Bandung: PT Remaja Rosdakarya. 